\title{
Influence of Culture Medium on Productivity and Nutrient Composition of the Housefly (Musca domestica) Maggot
}

\author{
Geneva Ojong Nkongho ${ }^{1 *}$, Bono Bono Severe Herve ${ }^{2}$, Aziwo T. Niba ${ }^{2}$, Amungwa Ivan \\ Tabikam $^{3}$, Mboglen David ${ }^{3}$, Ntyam Sylvie Carole ${ }^{3}$, Etchu, Kingsley Agbor ${ }^{4}$ \\ ${ }^{I}$ Institute of Agricultural Research for Development (IRAD), P.O Box 77 Batoke-Limbe, Cameroon \\ ${ }^{2}$ Department of Animal production technology, University of Bamenda, P.O Box 39 Bambili, Bamenda, \\ Cameroon \\ ${ }^{3}$ Institute of Agricultural Research for Development (IRAD), P.O Box 219, Kribi, Cameroon \\ ${ }^{4}$ Institute of Agricultural Research for Development (IRAD), P.O Box 2123, Yaoundé, Cameroon
}

*Corresponding Authors: Geneva Ojong Nkongho, Institute of Agricultural Research for Development (IRAD), P.O Box 77 Batoke-Limbe, Cameroon.

\begin{abstract}
Maggot meal, including that produced from the Housefly (Musca domestica) is a suitable substitute to fishmeal and soybean meal which are the conventional protein sources in diets of fish and livestock. Several types of culture media are used for maggot culture, but there is limited knowledge on their impact on maggot productivity and nutrient composition. The aim of this study was to access the impact of culture media on maggot productivity and nutrient composition. Maggot was cultured for 3 days in partial wooden boxes $(P W B)$ and complete wooden boxes $(C W B)$ using poultry manure supplemented with fish viscera. Maggot production was $0.0089 \pm 0.0002 \mathrm{~kg}$ and $0.0066 \pm 0.0002 \mathrm{~kg}$ on dry matter basis per $\mathrm{kg}$ poultry manure in $P W B$ and $C W B$, respectively. The dry matter, crude protein, fat, crude fibre, ash, nitrogen free extract and gross energy were $85.62 \pm 0.02 \%, 43.80 \pm 0.21 \%, 4.62 \pm 0.00 \%, 10.66 \pm 0.06 \%, 10.91 \pm 0.22 \%$, $30.14 \%$ and $4633.64 \pm 13.58$ (kcal/kg), respectively for maggot cultured in $P W B$ and $90.13 \pm 0.13 \%$, $42.07 \pm 0.23 \%, 8.38 \pm 0.01 \%, 11.81 \pm 0.40 \%, 17.22 \pm 0.11 \%, 20.59 \%$ and $4534.21 \pm 12.30$ ( $\mathrm{kcal} / \mathrm{kg})$, respectively for maggot cultured in CWB. The mean temperature in the boxes was $32-39^{\circ} \mathrm{C}$ and $32-42^{\circ} \mathrm{C}$ in $\mathrm{PWB}$ and $C W B$, respectively. Based on maggot productivity and maggot meal nutrient composition, the PWB is the preferred medium for housefly maggot culture.
\end{abstract}

Abbreviations: Complete wooden boxes (CWB), Maggot meal (MM), Partial wooden boxes (PWB), Institute of Agricultural Research for Development (IRAD)

Keywords: Culture enclosure, maggot meal, nutritional composition, poultry manure, temperature

\section{INTRODUCTION}

Feed cost represents $60-70 \%$ of meat production costs which is prohibitive and cannot be affordable by resource-poor farmers [1]. According to [2], the cost of feeding is a major factor affecting the development of fish farming. Based on the report of [3], the high cost of feeding is associated with the inclusion of the conventional protein sources like the fishmeal and soybeans meal which are very expensive. As a result, the focus of livestock and fish nutritionists has been to valorise alternative sustainable protein sources such as the maggot meal which can be produced easily using readily available by-products.

Maggot meal production is less costly and less tedious when compared with other sources of animal protein [4]; [5]. Maggots of the fly Musca domestica can be produced in large biomass using diverse agricultural by-products namely: pig dung, cattle blood, wheat bran, poultry manure, cattle manure [6]; [7]; [8]; [9]. However, according to [10], poultry manure is optimal for maggot culture.

Maggot meal (MM) contains nutrient values comparable to most high protein feedstuffs [11]; [9]. MM contains all the ten essential amino acids in quantities comparable to many animal proteins [6]. According to [12], MM contains higher amounts of some essential amino acids, namely cystine, 
histidine, phenyalanine, tryptophan and tyrosine than fish meal and soybeans meal. Meanwhile, [3] reported higher amounts of lysine and methionine in MM compared to fish meal.

MM has been reported as a substitute for fishmeal in fish feeds[3]; [13]; [14]; [15] and livestock feeds [11]; [16].

However, based on the report of [17], the development of maggot can be influenced by the culture medium, but there is limited information on the impact of culture medium on the development of the Housefly maggot. TheHouseflymaggots are cultured using different culture media. Therefore, the crucial question was if the different culture media do not have significant impact on the culture environment, maggot productivity and maggot nutrient composition. This question was the preoccupation of this particular study, since there is limited information on these aspects, despite the fact that maggot meal constitutes an important feedstuff in fish and livestock diets in Cameroon.

\section{Materials AND Methods}

\subsection{The Study Site}

This study was carried out at the Institute of Agricultural Research for Development (IRAD) - Kribi located between latitude $2^{\circ} 58^{\prime} 36.1377^{\prime} \mathrm{N}$ and longitude $9^{\circ} 55^{\prime} 02.285^{\prime \prime} \mathrm{E}$ in the Oecan Division, South Region of Cameroon. The climate of Kribi is classified as tropical. There is significant rainfall throughout the year. The average annual temperature is $25.7^{\circ} \mathrm{C}$, ranging from $24.5^{\circ} \mathrm{C}$ to $26.9^{\circ} \mathrm{C}$. Precipitation is about $2725 \mathrm{~mm}$ per year.

\subsection{Maggot Culture Media}

Two types of culture media (boxes) were used; the complete wooden boxes (CWB) and the partial wooden boxes (PWB). The CWB were constructed with plywood to cover the four sides and the bases, while the PWB were constructed with plywood to cover the four sides, but the bases were made of aluminium material. The top of all the culture boxes was covered with netting material to avoid predation by lizards and other predators.

\subsection{Maggot Production}

Two (2) $\mathrm{kg}$ each of poultry manure was moistened with clean borehole water $(0.5 \mathrm{~L})$ and fish viscera (fly attractant) $(0.5 \mathrm{~kg})$ was added to the manure; all treatments in triplicates. The content was thoroughly homogenized with gloved hands and exposed for 24 hours for natural egg deposition by flies. After exposure, all the boxes were covered with netting materials to avoid continuous deposition of eggs which could result in varied maggot sizes at harvest time and to prevent predation. The boxes were kept outdoors, under shade for three days for maggot development. During the cultivation period, water was sprinkled on the substrate on daily basis to keep it moist.

The temperature of thesubstrate in thedifferent boxes was monitored twice daily (morning and evening) to the nearest 1 degree using a digital thermometer.

To harvest the maggot at the end of three days, the content of each box (substrate and maggot) was poured onto a sieve dipped in slightly hot water and the blanched maggot was scooped from the surface of the water using a sieve. After harvest, maggot was weighed and solar dried for 24 hours. The dry maggot was thereafter grounded, packaged in air-tight polythene bags and conserved at $4{ }^{\circ} \mathrm{C}$ prior to proximate analysis.

\subsection{Proximate Analysis}

The proximate composition of maggot was determined following the method of Association of Analytical Chemists [18] by the Nutrition laboratory of the Department of Animal Production, University of Dschang, Cameroon. The nitrogen free extract (NFE) was calculated using the formula $=100-($ crude protein + fat + crude fibre + ash $)$.

\subsection{Statistical Analysis}

The data collected was subjected to one way analysis of variance (ANOVA) using the Statistical Package for the Social Sciences (SPSS) version 20.0 and group means differences tested at 95\% confidence interval. 


\section{RESULTS AND DISCUSSIONS}

\subsection{Maggot Production}

Maggot production on both wet and dry matter basis and the respective temperatures for the different culture media are presented in Tables 1 and 2, respectively. Maggot production in CWB was significantly $(\mathrm{P}<0.05)$ greater than the production in PWB. Similar with the study of [19], aluminium material favoured maggot development, probably due to the fact that temperature build-up was lower during the incubation process in PWB due to the insulating property of the aluminium material. Maggot yield recorded in this study was slightly higher than that reported by [10], probably due to the difference type of culture medium and fly attractant used.On the other hand, the yield in this study was lower than that of [1]. The disparity could be attributed to a shorter incubation period adopted in this study. Also, the disparity could be attributed to lower quantity of attractant used in this study; poultry manure to fish viscera ratio was 1:5 compared to 1: 3 used by [1]. Also, [20] recorded higher maggot production when compared to those reported in this study, probably due to variation in culture environment [21].

The temperature recorded in this study ranged between $32.1^{\circ} \mathrm{C}$ and $39.3^{\circ} \mathrm{C}$ inthe morning (8:00-9:00), and between $32.5^{\circ} \mathrm{C}$ and $38.5^{\circ} \mathrm{C}$ in the evening (17:00-18:00) for the PWB, while that for CWB ranged frombetween $32.1^{\circ} \mathrm{C}$ and $39.8^{\circ} \mathrm{C}$ in the morning, and between $33.3^{\circ} \mathrm{C}$ and $41.2^{\circ} \mathrm{C}$ in the evening. Mean temperaturebetween the treatments did not differ significantly $(\mathrm{P}>0.05)$. However, higher mean temperatures were recorded in CWB when compared to the PWB. The better production observed in PWB; where slightly lower temperatures were recorded indicated that the higher temperature observed in CWB was relatively less optimal for maggot development.

Table1. Wet weight of maggot/kg waste and their respective incubation temperature

\begin{tabular}{|l|l|l|l|}
\hline $\begin{array}{l}\text { Wet weight } \\
\text { maggot/kg } \\
\text { waste }\end{array}$ & Incubation material & Incubation Temperature $\left({ }^{\mathbf{0}} \mathbf{C}\right)$ & Production $(\mathbf{k g})$ \\
\cline { 2 - 4 } & Complete wooden box (CWB) & $36.55 \pm 2.94$ & $0.0528 \pm 0.0020$ \\
\cline { 2 - 4 } & Partial wooden box (PWB) & $34.54 \pm 2.46$ & $0.0666 \pm 0.0016$ \\
\hline
\end{tabular}

Table2. Dry weight of maggot/kg waste and their respective incubation temperature

\begin{tabular}{|l|l|l|l|}
\hline $\begin{array}{l}\text { Dry weight of } \\
\text { maggot } / \text { /kg } \\
\text { waste }\end{array}$ & Incubation material & Incubation temperature $\left({ }^{\circ} \mathbf{C}\right)$ & Production $(\mathbf{k g})$ \\
\cline { 2 - 4 } & Complete wooden box (CWB) & $36.55 \pm 2.94$ & $0.0066 \pm 0.0002$ \\
\cline { 2 - 4 } & Partial wooden box (PWB) & $34.54 \pm 2.46$ & $0.0089 \pm 0.0002$ \\
\hline
\end{tabular}

\subsection{Proximate Composition of Maggot}

The dry matter of maggot produced in PWB was significantly $(\mathrm{P}<0.05)$ less than that of maggot produced in CWB. Nevertheless, the dry matter contents of $85.62 \%$ and $90.62 \%$ in PWB and CWB, respectively, in this study were slightly lower than those reported by [22]; [3]; [11]. This disparity could be attributed to the quality of poultry manure used and even the culture environment. For crude protein, that of PWB was significantly $(\mathrm{P}<0.016)$ greater than that in CWB. However, the crude protein contents of the $43.7 \%$ and $42.06 \%$ recorded in this study were all lower than those of [3]; [16], but were similar to that of [23] whereby poultry manure was also used for maggot culture. The crude fat for maggot cultured in PWB, was significantly $(\mathrm{P}<0.05)$ less than that of maggot cultured in CWB. Regarding crude fibre component, there was no significant $(\mathrm{P}>0.55)$ difference between the treatments, although higher crude fibre contents were recorded in CWB. The ash contents of maggot produced in $\mathrm{PWB}$ were significantly $(\mathrm{P}<0.05)$ less than that of maggot produced from $\mathrm{CWB}$. Concerning the organic matter, maggot produced in $\mathrm{PWB}$ showed significantly $(\mathrm{P}<0.05)$ higher values that of maggot produced in CWB. The crude energy for maggot cultured in PWB was also significantly $(\mathrm{P}<0.05)$ greater than that of maggot cultured in CWB. Table3 presents the proximate components and compositions of the two treatments. Notwithstanding, the crude fat, ash fibre and metabolizable energy contents recorded in this study differed significantly from those of [23]; [16] where maggot was cultured using poultry manure probably due to differences culture condition and the incubation period. [16] cultured maggot on the soil and harvested after four to five days as compared to this study where culture was carried out in boxes and maggots harvested after three day. 
Influence of Culture Medium on Productivity and Nutrient Composition of the Housefly (Musca domestica) Maggot

Table3. Proximate components and compositions for the two culture milieu

\begin{tabular}{|l|l|l|}
\hline Proximate component & Complete wooden boxes & Partial wooden boxes \\
\hline Dry matter (\%) & $90.13 \pm 0.13^{\mathrm{a}}$ & $85.62 \pm 0.02^{\mathrm{b}}$ \\
\hline Crude protein (\%) & $42.07 \pm 0.23^{\mathrm{a}}$ & $43.80 \pm 0.21^{\mathrm{b}}$ \\
\hline Fat (\%) & $8.38 \pm 0.01^{\mathrm{a}}$ & $4.62 \pm 0.00^{\mathrm{b}}$ \\
\hline Crude fibre (\%) & $11.81 \pm 0.40^{\mathrm{a}}$ & $10.66 \pm 0.06^{\mathrm{a}}$ \\
\hline Ash (\%) & $17.22 \pm 0.11^{\mathrm{a}}$ & $10.91 \pm 0.22^{\mathrm{b}}$ \\
\hline NFE (\%) & $20.59^{\mathrm{a}}$ & $30.14^{\mathrm{b}}$ \\
\hline Gross energy $(\mathrm{kcal} / \mathrm{kg})$ & $4534.21 \pm 12.30^{\mathrm{a}}$ & $4633.64 \pm 13.58^{\mathrm{b}}$ \\
\hline
\end{tabular}

"Means on the same row with the same superscript are not significantly different

\section{CONCLUSION}

Both CWB and PWB can be used for the culture of maggot, since the nutrient composition of the maggot obtained in this study was comparable to those earlier reported. However, maggot productivity and nutritional composition was influenced by the type of culture medium used. This study revealed that CWB allowed temperature build-up within the box, which although was not significantly higher than the temperature in PWB, resulted to significant differences in maggot productivity and nutrient composition. Maggot productivity and nutritional composition in the PWB were better than in CWB. Therefore, the PWB is recommended for maggot production when compared with CWB.

\section{ACKNOWLEDGEMENT}

We are grateful to the Institute of Agricultural Research for Development (IRAD), Kribi for providing working space for this research.

\section{REFERENCES}

[1] Dzepe D., Nana P., Tchuinkam T., Meutchieye F., Lontsi M. D., Tchoumbou M. and Kimpara J.M., Production and Valorization of Maggot Meal: Sustainable Source of Proteins for Indigenous Chicks. Asian. J. Res. Anim. Vet.Sci. 3(3), 1- 9 (2019).

[2] Pouomogne, V., Capture-based aquaculture of Clarias catfish: case study of the Santchou fishers in western Cameroon. In: Lovatelli, A. and Holthus, P.F. (eds). Capture-based aquaculture. Global overview. FAO Fisheries Technical Paper. No.508.Rome, pp 93-108 (2008).

[3] Aniebo A. O., Erondu E. S. and Owen O. J., Proximate composition of housefly larvae (Musca domestica) meal generated from mixture of cattle blood and wheat bran, Livest. Res. Rural. Dev.20(12),1-5 (2008).

[4] Ajani E. K., Nwanna L. C. and Musa B. O., Replacement of fishmeal with maggot meal in the diets of Nile tilapia (Oreochromis niloticus), World. Aquac. 35(1), 52 - 54 (2004).

[5] Anene A., Olivia C., Ike K. and Ekekwe N. H.,Preliminary investigations on quantity and proximate quality of maggots produced from four different sources of livestock wastes, J. Res. Biol.3(6), 1060 1065(2013).

[6] Akpodiete O .J, Ologhobo A. D. and OluyemiJ. A., Production and nutritive value of housefly maggot meal on three substrates of poultry faeces, J. Appl. Anim. Res.12(1),101- 106 (1997).

[7] Aniebo A. O. and Owen O. J., Effects of age and method of drying on the proximate composition of housefly larvae (Musca domestica, Linnaeus) meal (HFLM), Pak. J. Nutr. 9(5), 485 - 487 (2010).

[8] Čičková H., Pastor B., Kozánek M., Martínez-Sánchez A., Rojo S. and Takáč P., Biodegradation of Pig Manure by the Housefly, Musca domestica: A Viable Ecological Strategy for Pig Manure Management. PLOS ONE. 7(3), 1-9 (2012).

[9] Hussein M., Pillai V. V., Goddard J. M., Park H. G., Kothapalli S., Ross D. A., Ketterings Q. M., Brenna J. T., Milstein M. B., Marquis H., Johnson P. A., Nyrop J. P. and Selvaraj V., Sustainable production of housefly (Musca domestica) larvae as a protein-rich feed ingredient by utilizing cattle manure. PLOS ONE. 12(2), 1-19(2017).

[10] Hezron L., Madalla N. and Chenyambuga S.W., Mass production of maggots for fish feed using naturally occurring adult houseflies (Musca domestica). Livest. Res. Rural Dev. Volume 31, Article \#57. Retrieved October 6, 2019, from http://www.lrrd.org/lrrd31/4/lhlut31057.html

[11] Hwangbo J., Hong E. C., Jang A., Kang H. K., Oh J. S., Kim B. W. and Park B. S., Utilization of house fly-maggots, a feed supplement in the production of broiler chickens. J. Environ. Biol. 30(4), 609 - 614 (2009). 
[12] Adesulu E. A. and Mustapha A. K., Use of housefly maggots as a fishmeal replacer in tilapia culture: A recent vogue in Nigeria. Pages 138-143 In K. Ftzimmons and J.C. Filho, editors. Proceedings of the Fifth International Symposium on Tilapia Aquaculture, Rio Dejaneiro, Brazil, (2000).

[13] Ogunji J. O., Kloas W., Wirth M., Neumann N. and Pietsch C., Effect of housefly maggot meal (magmeal) diets on the performance, concentration of plasma glucose, cortisol and blood characteristics of Oreochromis niloticus fingerlings. J. Anim. Physiol. Anim. Nutr. 92, 511-518 (2008).

[14] Ajonina A. S. and Nyambi R. E., Evaluation of growth response of Clarias gariepinus fingerling feddried maggot as protein source, Int. J. Curr. Microbiol. App. Sci. 2(5), 123 -129 (2013).

[15] Djissou A. S. M., Adjahouinou D. C. and Fiogbe E. D., Complete replacement of fish meal by other animal protein sources on growth performance of Clarias gariepinus fingerlings, Int. Aquat. Resour. 8,333-341 (2016).

[16] Mbiba H. F., Etchu K. A. and Ndamukong K., Carcass Characteristics, Hematology, Serum Chemistry, and Enzymes in Broiler Chickens Fed Maggot Meal as a Protein Substitute for Fishmeal. Glob. J. Med. Res.19(1), 7-13(2019).

[17] Shumo M., Khamis F. M., Tanga C. M., Fiaboe K. K. M., Subramanian S., Ekesi S., Van Huis A. and Borgemeister C., Influence of temperature on selected life-history traits of Black Soldier Fly (Hermetia illucens) reared on two common urban organic waste streams in Kenya. Anim. 9(79), 1-14 (2019).

[18] AOAC. (1990). Official methods of analysis. $14^{\text {th }}$ edn. Assoc. of Official Analytical Chemists, Washington DC.

[19] Ezewudo B. I., Monebi C. O. and Ugwumba A. A. A., Production and utilization of Musca domestica maggots in the diet of Oreochromis niloticus (Linnaeus, 1758) fingerlings. Afr. J. Agri. Res. 10(23), 2363 -2371 (2015).

[20] Koné N., Sylla M., Nacambo S. and Kenis M., Production of house fly larvae for animal feed through natural oviposition. J. Insects as Food and Feed.3(3), 177-186.(2017).

[21] Lysyk T. J. and Axtell R. C., Movement and distribution of House flies (Diptera: Muscidae) between habitats in two livestock farms. J. Econ. Entomol. 79(4), 993 - 998 (1986).

[22] Teguia A., Mpoame M. and Mba J. A. O., The production performance of broiler birds as affected by the replacement of fish meal by maggot meal in the starter and finisher diets. Tropicultura. 4,187-1 92(2002).

[23] Okah U. and Onwujiariri E. B., Performance of finisher broiler chickens fed maggot meal as a replacement for fish meal. J. Agric. Technol. 8(2), 471 - 477 (2012).

Citation: Geneva Ojong Nkongho et al., "Influence of Culture Medium on Productivity and Nutrient Composition of the Housefly (Musca domestica) Maggot", International Journal of Research Studies in Biosciences, 8(6), pp. 5-9. DOI: https:// doi.org/10.20431/2349-0365.0806003

Copyright: (C) 2020 Authors, This is an open-access article distributed under the terms of the Creative Commons Attribution License, which permits unrestricted use, distribution, and reproduction in any medium, provided the original author and source are credited. 